\title{
Results of Geophysical Survey in Bargat El-Shab in Southern Egypt. Insight into the Early Holocene Settlement Pattern of the El Nabta/Al Jerar Interphase
}

\author{
Fabian Welc ${ }^{a}$ and Przemysław Bobrowski ${ }^{b}$
}

\begin{abstract}
Global climatic changes which occurred at the beginning of the Holocene had a huge impact on cultural development in northeast Africa. The shift of the tropical rain zone to the north led to the transformation of the desert into a savannah. The appearance of vegetation and animals also attracted people to considerable areas of the southern part of the Western Desert in Egypt. Settlement was concentrated around natural depressions or deflation troughs, which during periods of rain would fill with water creating seasonal lakes or playas. One such place is the playa located in Bargat El-Shab. Particularly intense traces of settlement dated to the climatic optimum of the Holocene was discovered on the eastern shore of the palaeolake (Site E-05-1). Artefacts are dispersed over an area of over 2 ha. Excavation conducted in a few locations also uncovered the remains of storage pits, hearths, wells, etc., the fills of which are characterised by an enhanced magnetization of features in the ground. The geophysical survey conducted during the last season of research provided exceptionally interesting data allowing the partial recreation of the actual extent of the site and its relation with the lake basin.
\end{abstract}

KEY-WORDS: Early Holocene, Western Desert, settlements, magnetometry

\section{INTRODUCTION}

In 20I9, a survey was conducted at the Bargat El-Shab site using a gradiometer to define the range and spatial structure of early Holocene settlement of the El Nabta / Al Jerar phase. The premise behind this survey was also to enable designation of the border between the coastal zone of the early Holocene reservoir and the settlement structures.

a Institute of Archaeology, Cardinal Stefan Wyszyński University, Kazimierza Wóycickiego Street I/3, oI-938 Warsaw, Poland; e-mail: fabian.welc@wp.pl; ORCID: 0000-0001-6122-1884

$b$ Institute of Archaeology and Ethnology, Polish Academy of Sciences, Rubież Street 46, 6I-6I2 Poznan, Poland; e-mail: przemyslawbobrowski@iaepan.poznan.pl; ORCID: 0000-0002-7537-1856 
222 Fabian Welc and Przemystaw Bobrowski

For this purpose, profiling was applied with the use of a gradiometer within the measurement area located at Site E-05-1. The site is situated on the eastern edge of the basin, on a small elevated monadnock, made of Nubian sandstone and covered with a layer of lacustrine silty sands. The entire surface of the site, spanning around $250 \mathrm{~m}$ along the NS axis and IOO-I50 $\mathrm{m}$ along the EW axis, is covered with the remains of prehistoric settlement forming smaller and larger concentrations. The most legible concentration of artefactual material on the surface was observed within two distinct summits of the monadnock mentioned. Initial surface studies and excavations ${ }^{1}$ were conducted within the area of two trenches E-05-1/1 and E-05-1/2 established at the locations of heavy concentration of stone artefacts on the surface (Bobrowski et al., 20IO). In the first trench, within a morphologically homogeneous layer, the presence of artefactual material from a variety of settlement phases was recorded, beginning with the oldest phase associated with the El Adam population, through artefacts associated with settlement of the climatic optimum of the Holocene of the damp El Nabta / Al Jerar phase to younger Neolithic settlement phases, referred to as Middle and Late Neolithic (Schild and Wendorf 20I3: 128). The creation of this layer is associated with the exceptionally heavy deflation of the site and post-depositional processes. In the second trench, under a layer $5-30 \mathrm{~cm}$ thick also containing mixed multi-phase artefactual material, the bases of features - storage pits and hearths - were registered. The fills of these features contained quite frequent artefactual and archaeobiological material, including burnt plant remains. The typological analysis of the artefactual material, confirmed by absolute dating of the macroremains of plants, allows us to associate these features with the Late early Holocene El Nabta / Al Jerar settlement phase (Bobrowski et al., 2010; 2020; Bobrowski 2019: 120).

The nearly homogeneous image of the entire surface, including the lack of any legible traces of archaeological structures on the surface makes recognition of the actual structure and extent of the settlement within the site described quite difficult. As mentioned above, recognition of the relation between prehistoric settlement and the Early Holocene lake reservoir was of particular significance. Given the limited time resources and the extent of regular excavation studies, the only chance here was to perform a non-invasive geophysical survey (magnetometer), based on magnetic anomalies that indicate the presence of fills of underground structures (pits and hearths) in certain locations (trenches E-05-1/2, E-05-1/4 and E-05-1/5) cause.

1 The research was led by Przemysław Bobrowski as a part of the Combined Prehistoric Expedition in $2005-2006$ and $2011-2012$. 


\section{GEOLOGICAL AND GEOMORPHOLOGICAL SETTING}

The El Bargat El-Shab playa is located about $16 \mathrm{~km}$ from Gebel Nabta (Nubia-Sheb Pediplain; see Osman 1999; Wendorf et al., 200I: IIf). The catchment area of the Bargat El-Shab playa, which occupied a shallow depression at the foot of Gebel Bargat and measure up to $6 \mathrm{~km}^{2}$ (Fig. I). The central part of the basin is irregular in shape, about $4 \mathrm{~km}$ long along the northeast to south axis, and about $2 \mathrm{~km}$ wide in the east-west direction. The shape of the basin is determined by outcrops of erosion-resistant rocks to the west and east. Lake in Nabta Playa, the floor of the basin is covered by quaternary deposits, mostly composed of lacustrine and windblown sands created as a result of deflation processes during the Late Holocene (Wendorf et al., 200I)

From a geological point of view, the area around Gebel Bargat El-Shab and Nabta Playa is dominated by a Maastrichtian-Eocene sedimentary succession divided into four main rock units: the Dungul Formation (late Eocene limestones), the Garra Formation (late Eocene-upper Palaeocene shales), the Kurkur Formation (Palaeocene limestones). The Late Cretaceous-Early Tertiary succession in the El Berget area is composed mostly of silty shales alternating with limestones. This sequence overlies a sandstone unit

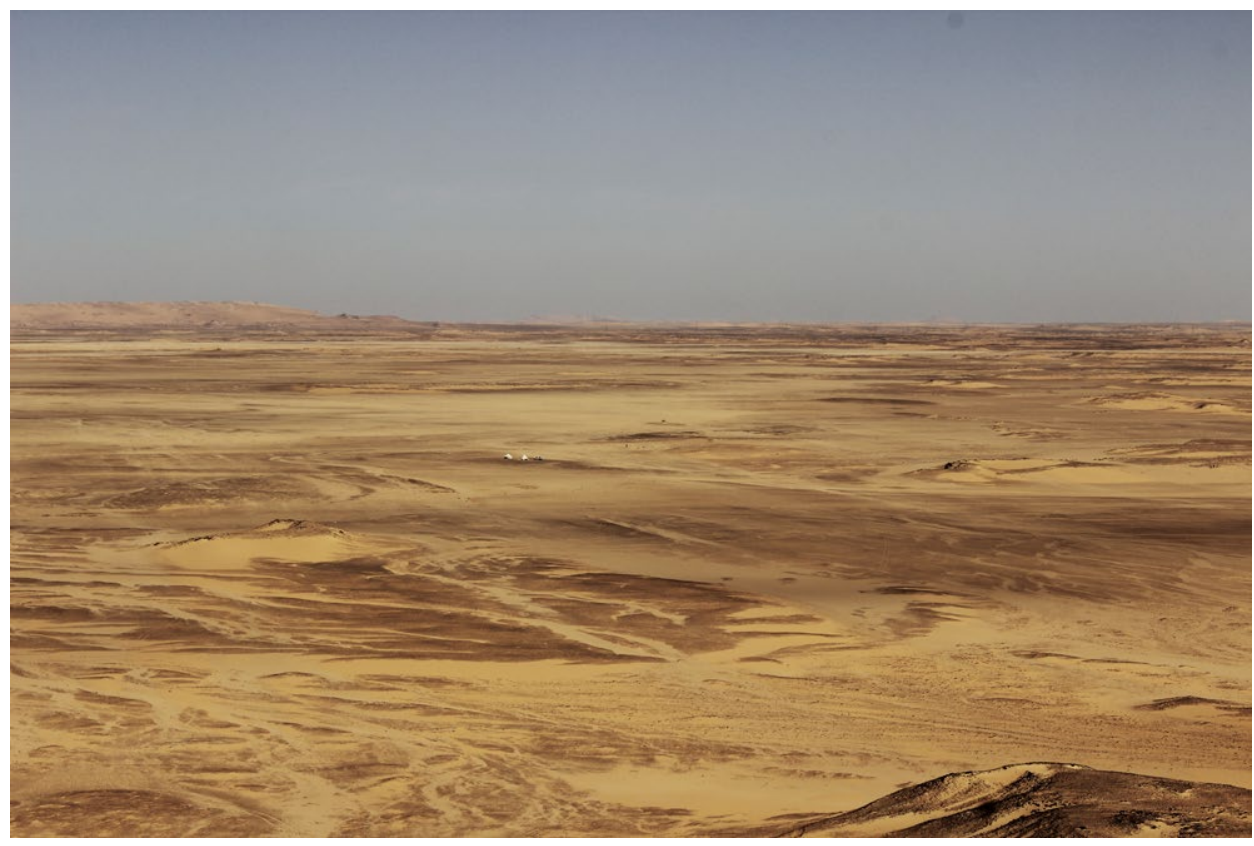

Fig. I. View of the El Bargat playa basin from the top of Gebel Bargat El-Shab. Photo F. Welc. 
224 Fabian Welc and Przemystaw Bobrowski

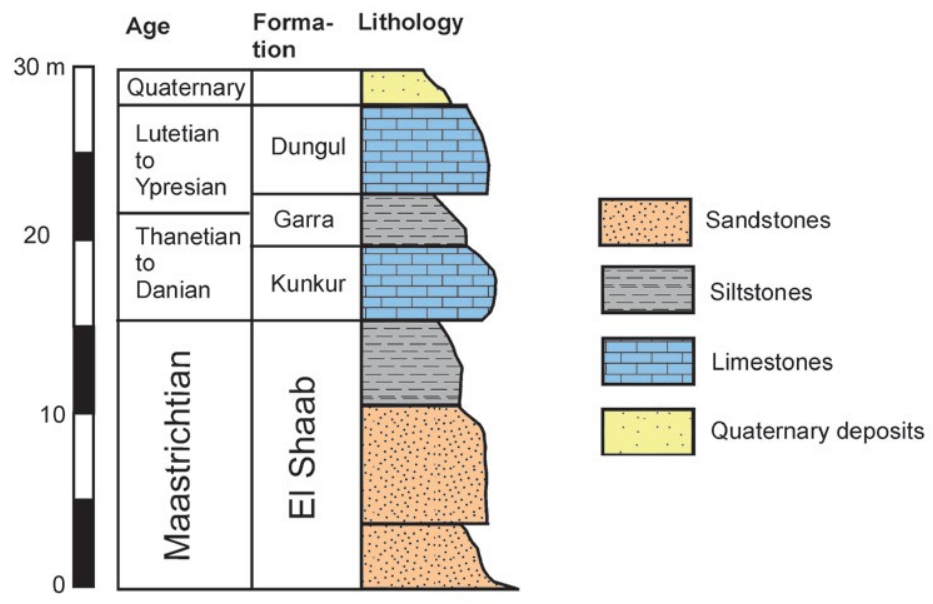

Fig. 2. The Late Cretaceous-Early Tertiary succession in the Bargat El-Shab area is composed mostly of silty shales alternating with limestones (after Sherbini et al., I989, modified by F. Welc).

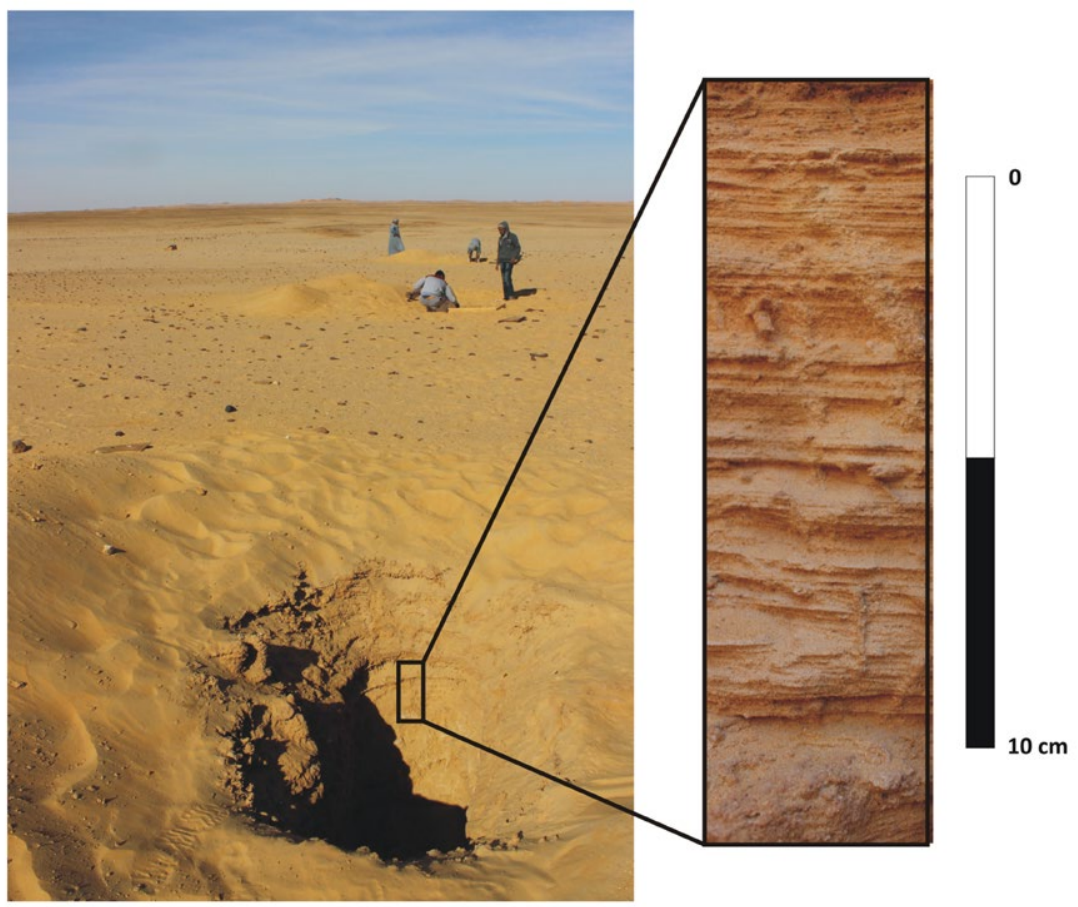

Fig. 3. The thin layered lacustrine silty sands which occupy the lowermost part of the basin in Bargat El-Shab are covered by windblown sand. Photo: F. Welc. 
belonging to the Nubia Formation (Issawi 1971; Klitzsch 1983; Sherbini et al., 1989; Fig. 2). In the Berget El-Shab area, the Garra formation comprises a $4 \mathrm{~m}$ thick bed of grey gypsiferous shale and underlies the Dungul Formation. The first formation is represented by a white, hard limestone bed ( $5 \mathrm{~m}$ thick) exposed on the top of Gebel Bargat El-Shab (Sherbini etal., 1989). Early Holocene, thin layered lacustrine silty sands which occupy the lowermost part of the Bargat El-Shab basin are covered by a thin layer of windblown sands (Fig. 3).

This part of the basin filled with palaeolake sediments measures about $2 \mathrm{~km}$ by $2 \mathrm{~km}$. Thickness of this succession is difficult to established, but in the deepest part of the basin it can be estimated to reach a few metres. In the littoral zone of the basin, interbedded sands and silts layers contain numerous calcareous marshy (reed) plant casts. Numerous tributaries are entering the Bargat Basin from all directions. During time of their activity silty-sand deposits interbedded with alluvial sediments form wadis draining the surrounding desert were deposited. Similar like in Nabta Playa deposited layered lacustrine silts in El Berget are result of precipitation of suspended matter during inundation season. In result they are poorly sorted as a result of the admixture of coarse windblown sand accumulated during arid intervals (Wendorf et al., 200I).

\section{METHODOLOGY}

In general, magnetometer surveying is used to detect very small changes in the Earth's magnetic field caused mostly by concentrations of ferrous minerals in the soil (Herwanger et al., 2000; Fassbinder 2005; 2015; Aspinall et al., 2008). It should be emphasized here that the formation of the iron oxides in the soil is a very complex process, which depends on geochemistry, erosion rates, biological activity and local climate conditions (Evans and Heller 2004; Maher 20II; Fassbinder 20I5). The anomalies observed on magnetic maps indicate remnant magnetism which is associated with sediments or features enriched with fine-grained magnetic particles affected by the magnetic field and inducted magnetism connected with sediments or materials which retain past magnetism (Fassbinder et al., 20II; Fassbinder 20I5; 20I7). If sediments or other buried features were exposed to high temperatures, they became magnetized by thermoremanent magnetization (TRM; Fassbinder 20I5; 20I7). Because nearly all types of organic sediments like soils are characterized by enhanced magnetization (Armstrong et al., 2012; Fassbinder 2015), anthropogenic pits or ditches refilled by topsoil generate distinctive positive magnetic anomalies (high values of nT). In contrast, negative anomalies may have numerous causes (Fassbinder 2017). Areas where there are remains of hearths or stones rich in magnetic minerals very often appear on magnetic maps as distinctive high amplitude features (Welc et al., 2019). 


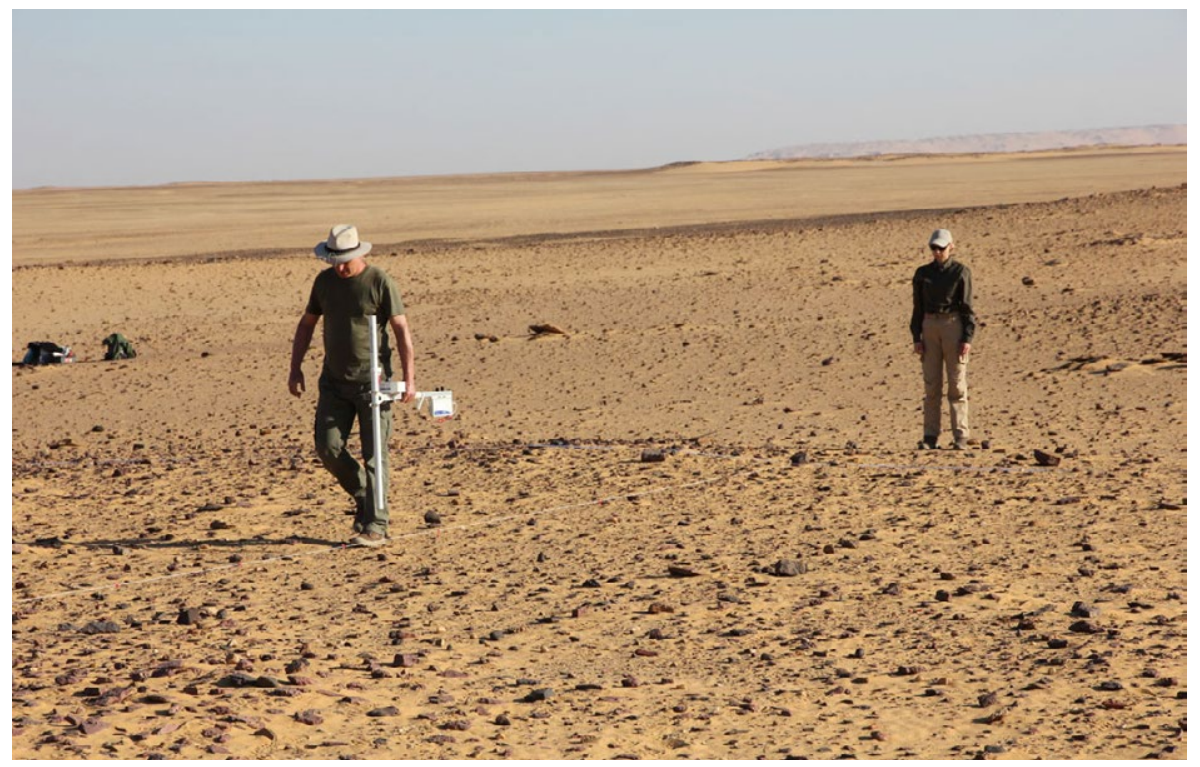

Fig. 4. At Bargat El-Shab, gradiometer data was collected using the Bartington Grad 601 gradiometer with single sensor placed close to the ground (approx. $20 \mathrm{~cm}$ above the surface). Photo: P. Bobrowski.

At Bargat El-Shab, data were collected using the Bartington Grad 601 gradiometer equipped with single sensor (Fig. 4). Three adjoining grids of $40 \times 30 \mathrm{~m}$ were measured with profiles spaced at $50 \mathrm{~cm}$ and 4 measurement points collected per metre; the data were then processed and filtered to generate magnetic maps using the TerraSurveyer software. In the first step, the DeStripe filter was used to equalize differences between grids. In the next step, a clipping procedure was used, which is very useful to replace extreme amplitude values outside a specified minimum and maximum, in this case in the range from -5 to $4.3 \mathrm{nT}$. Finally, the interpolation procedure was applied to increase the resolution of obtained maps of distribution of magnetic anomalies. The final procedure applied was the Low Pass filter to remove low frequency values in a data set (for more on these procedures see: www.dwconsulting.nl).

\section{RESULTS AND DISCUSSION}

As mentioned above, at Bargat El-Shab gradiometer data were collected within three adjoining grids with dimensions of $40 \times 30 \mathrm{~m}$. This $120 \mathrm{~m}$ long strip partially covers the littoral zone of the early Holocene basin and the northern part of the El Nabta / Al Jerar phase settlement marked as E-05-1 and oriented on the NE-SW axis (Fig. 5). 
The results of magnetic measurements are presented below in form of black - white maps of distribution of the anomalies (called positive mode). On such maps dark areas correspond to the high amplitude anomalies measured in nanoteslas $-\mathrm{nT}$, while lighter areas correspond to lower values of magnetic field strength. In other words, the areas in black indicate a concentration of sediments rich in ferromagnetic minerals; in most cases such areas are effect of extensive past human activity (Welc et al., 2019).

The magnetic map indicates the presence of numerous highly magnetic zones (darker areas) round in shape (Fig. 5). These positive magnetic readings are a function of an accumulation of organic matter or ashes. It is important to note here that areas with remains of hearths very often appear on magnetic map as a distinctive feature - so called dipoles marked by a pair positive and negative point anomalies with a north - south orientation. Without a doubt, concentrations of the positive magnetic anomalies seem to show

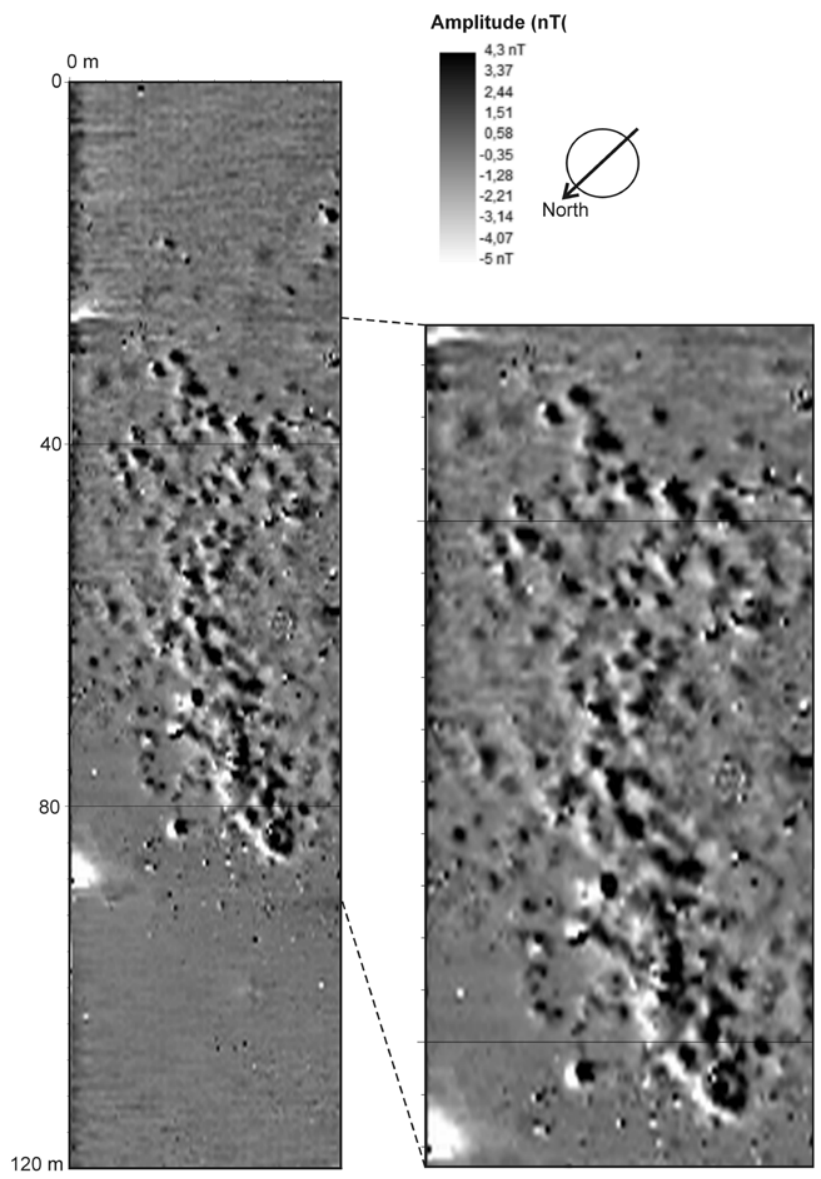

Fig. 5. Results of the magnetic survey carried out at Site E-05-1. Photo: F. Welc. 
228

evidence of human activity in the zone, but their age and stratigraphic context could not be determined using only magnetic maps (Welc et al., 2019).

As mentioned above, the magnetic image reveals the concentration of numerous oval-shaped anomalies that on the basis of analysis of their amplitude value can be identified as remains of hearths or storage pits. Moreover, we can see that some of these anomalies overlap each other, suggesting that the site had several phases of occupation. These assumptions confirm the results of excavations carried out at trenches E-05-1/4 (within the tested area) and E-05-1/2 (within the northern summit of the monadnock; Fig. 6). Characteristic oval features with a diameter of about $\mathrm{I}-2 \mathrm{~m}$ were uncovered there, most of which are remains of hearths. Within some of them, burnt stones have also been preserved that give a strong magnetic signature on the presented map (Figs. 5 and 7 ).

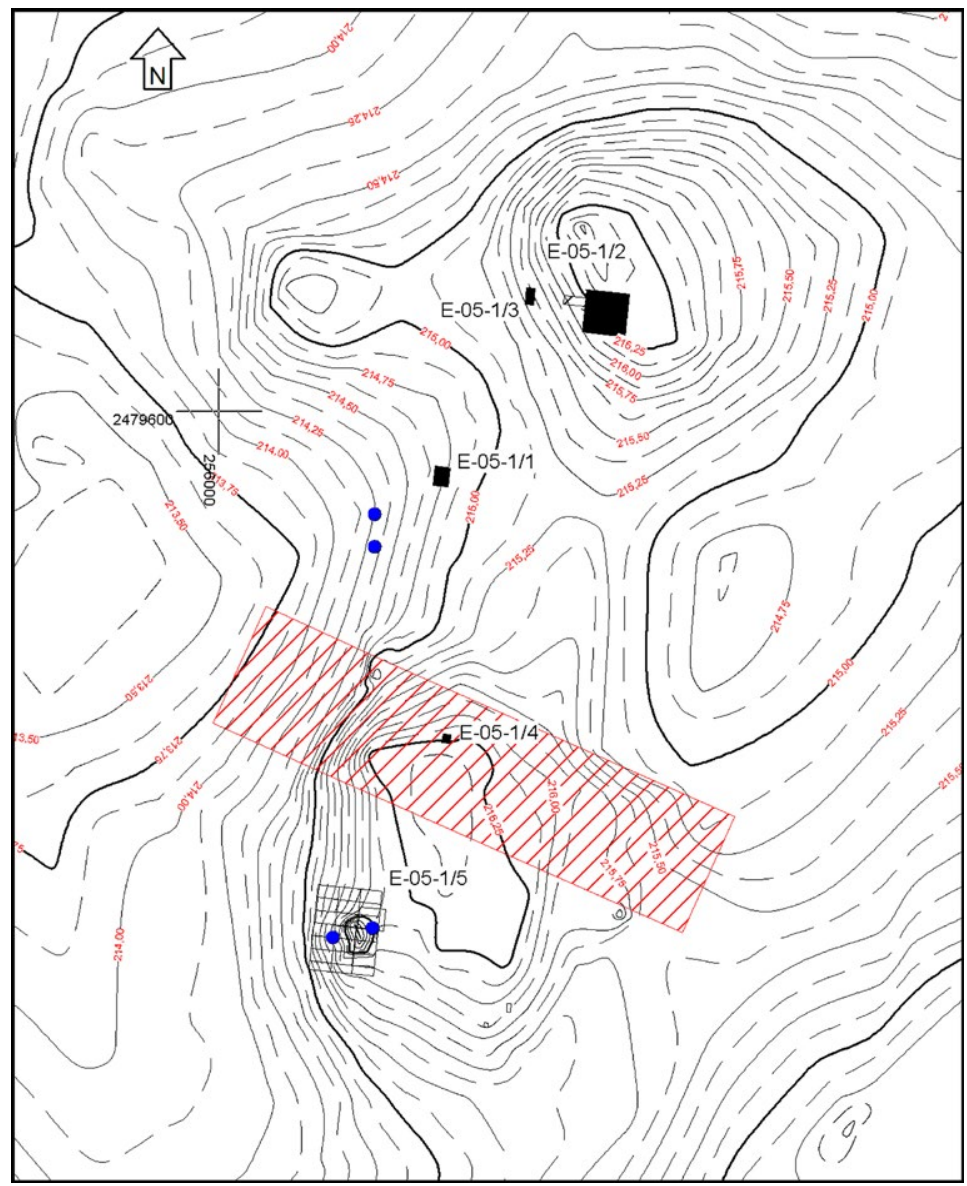

Fig. 6. Map of the archaeological Site E-05-1 excavated in the Bargat El-Shab area. Drawn: P. Wiktorowicz. 
Results of Geophysical Survey in Bargat El-Shab in Southern Egypt...

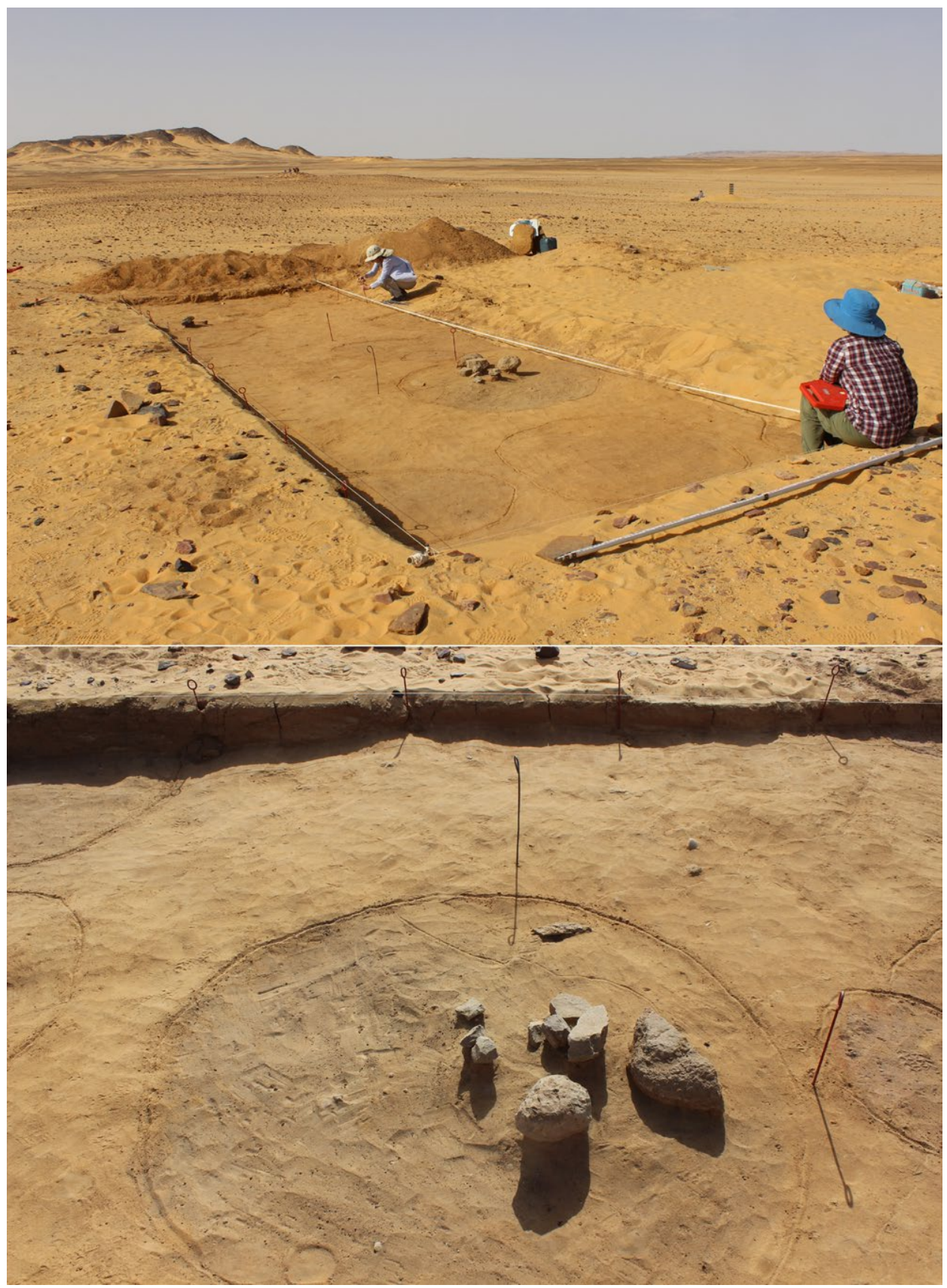

Fig. 7. Remains of the early Holocene hearths and pits excavated within the Site E-05-1/2. Photo: F. Welc. 
$230 \mid$ Fabian Welc and Przemystaw Bobrowski
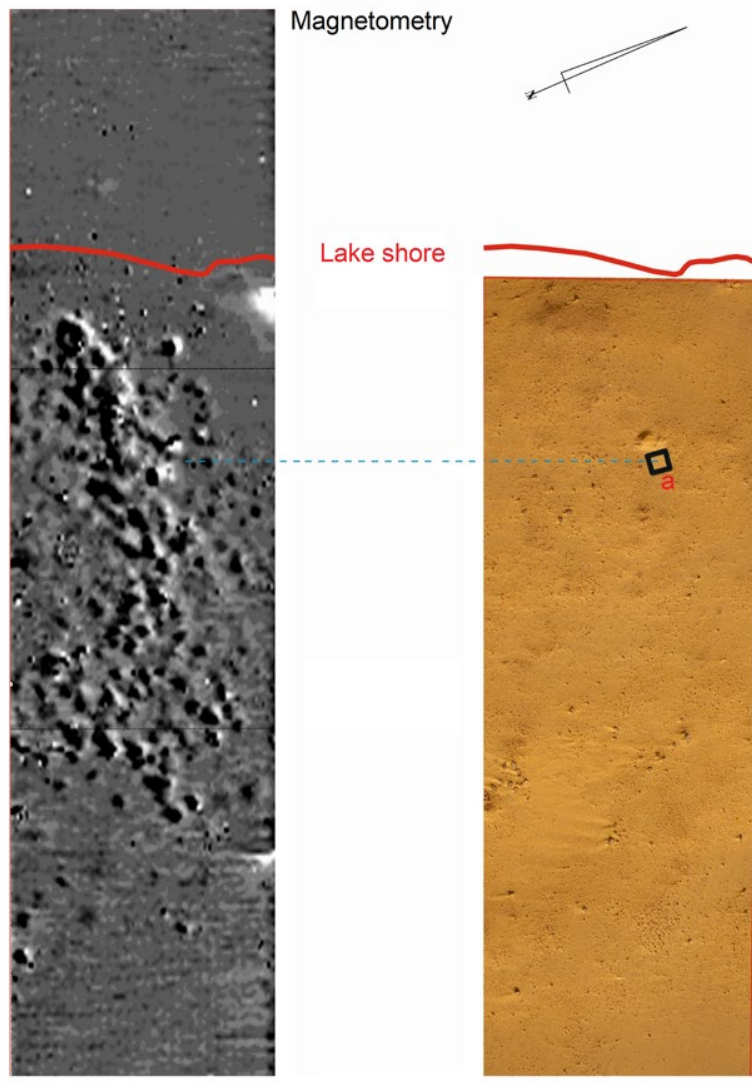

0

40
Fig. 8. Magnetic map and Google image of the early Holocene settlement with east edge of the former lake and trench E-05-1/4 (a) marked. Drawn and photo: F. Welc and P. Wiktorowicz.

Very interesting information was obtained after comparing and applying the magnetic map to the topographic map (Fig. 8). This combination allows us to draw a border between the edge zone of the former Holocene lake and a small flat elevation on which the Neolithic settlement of the El Nabta / Al Jerar phase was located. It is clear that the remains of hearths and storage pits are concentrated on gentle elevation slopes, probably above the highest water levels in the lake. It is interesting that the flat top of the hill does not seem to be occupied by hearths and other settlement structures. From the east, magnetic studies also do not reveal clear traces of settlement. On the one hand, we can assume that the lack of features on the southern summit of the monadnock is the result of a heavy deflation of the site, which completely levelled any features in the ground in that part. On the other hand, however, we cannot rule out that the image presented on the magnetic map reflects a completely different function (non-utility) of this part of the El Nabta / Al Jerar site. The clear lack of features on the magnetic map 


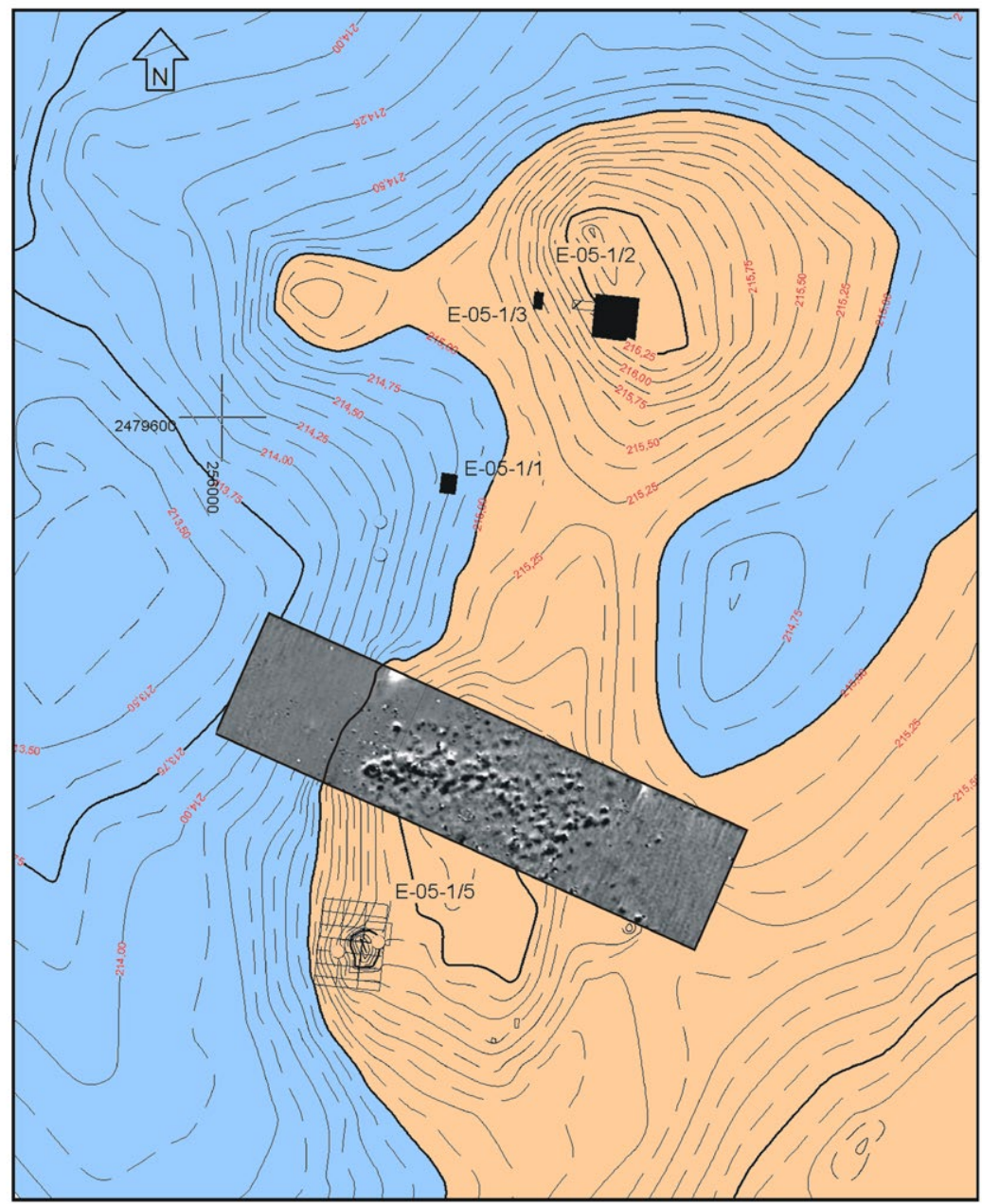

Fig. 9. Magnetic plan and elevation map with east edge of the former lake (blue). Drawn: F. Welc and P. Wiktorowicz.

in the eastern and western part of the tested area (from the direction of the palaeolake) reflects the actual extent of the site (Fig. 8). The situation in the northern part is not as clear, as there we can also observe a slight dispersion of the features. This fragment of the tested area partially comprises a visible depression between both summits of the monadnock. This could perhaps be a natural border between parts of the settlement or between two separate settlements from the same El Nabta / Al Jerar time horizon. We also cannot exclude the possibility that deflation in this part of the site was stronger and hence the distinct dispersion or lack of features (Fig. 8). 
232 Fabian Welc and Przemystaw Bobrowski

The analysis presented above allows us to reach some important conclusions. The multi-phase El Nabta / Al Jerar period settlement was located on a local elevation, which in the period of high lake water levels would have been a peninsula (Fig. 9). The concentration of most settlement remains in the flood-free land level by the lake suggests that people appeared around the reservoir during the rainy period, e.g., the summer monsoon. As mentioned above, the basal sediments of the lake are mainly thin layers of sandy silts interlaced with coarse windblown sands, which allows us to classify this palaeolake as a sandy playa. This indicates that during rainfall, the lake was filled with water, while in the winter season the reservoir would partly or completely dry up. In the El Nabta / Al Jerar period therefore this forced seasonal migration of people that lasted from summer to autumn. In winter, most likely, people migrated south or towards the Nile Valley, but this theory needs to be supported by additional specialized research and analysis, particularly of the playa deposits preserved at Bargat El-Shab.

\section{CONCLUSIONS}

The geophysical survey conducted at Site E-05-1 which took advantage of the enhanced magnetization of features in the ground (utility pits and hearths) allowed us to recognize the structure of Holocene settlement within the site and define its actual scope. The correlation of the magnetic and topographic map enabled us to specify the maximum reach of the palaeolake and the actual shape of the site during the climatic optimum of the El Nabta / Al Jerar phase of the early Holocene. We were able to determine its eastern and western reach and the internal zones of feature dispersion (southern summit and depression between two summits of the monadnock). Although random, the image obtained thanks to the geophysical survey considerably differs from the situation observed on the surface of the site. The artefactual material registered on the surface is scattered over an area which is significantly larger than the actual extent of the site. This is most likely the result of post-depositional processes. On the surface of the site, there is a lack of distinct traces of features in ground, which appear under a relatively homogeneous layer of silty sand at a depth ranging from a few to several dozens of centimeters. The excavation work conducted within several trenches in various parts of the Site (E-05-1/2, E-05-1/4, E-05-1/5) allowed us to register features in ground with a very uniform chronology. The absolute dating performed for most of them enable us to associate all with the late Early Holocene represented by the El Nabta / Al Jerar settlement phase. We can presume that the concentration of features visible on the magnetic map (in this part also the features registered in trench E-05-1/4) represent the same time horizon. Their mutual relations are most likely the effect of multiple, probably seasonal, occupation of this location. Verification of this thesis, knowledge of the actual chronology, functions and mutual relationships 
of features in ground will be possible once we conduct regular excavations in the area that was surveyed using geophysical methods, as was possible in trench E-05-1/2 at the northern end of the settlement.

\section{ACKNOWLEDGEMENTS}

The research was sponsored by the Polish National Science Centre (grant NCN No. 2015/17/B/HS3/01315).

\section{REFERENCES}

Armstrong, A., Quinton, J. and Maher, B. 20I2. Thermal enhancement of natural magnetism as a tool for tracing eroded soil. Earth Surface Processes and Landforms 37: 14-20.

Aspinall, A., Gaffney, C. F. and Schmidt, A. 2008. Magnetometry for Archaeologists. New York, Toronto, Plymouth Altamira Press, Lanham.

Bobrowski, P. 2019. Berget el Sheb, Western Desert, Egypt. In M. Chłodnicki and P. L. Polkowski (eds), Gdy Sahara byta zielona. Polskie badania nad prahistoria Afryki Pótnocnej (When Sahara was Green. Polish archaeological research on the prehistory of North Africa), II9-I24. Poznań.

Bobrowski, P., Jórdeczka, M., Mańka, D., Królik, H., Schild, R. and Wendorf, F. 20ıo. The Combined Prehistoric Expedition in Nubia 2003-2008. Gdańsk Archaeological Museum African Reports 6: 15-30.

Bobrowski, P., Jórdeczka, M., Lityńska-Zając, M. and Osypińska, M. 2020. The Early Holocene archaeological evidence (site E-05-1) in Bargat El-Shab (Western Desert Egypt). Archaeologia Polona 58: I95-220.

Evans, M. E. and Heller, F. 2004. Environmental Magnetism. Amsterdam.

Fassbinder, J. W. E. 2005. Methodische Untersuchungen zur Magnetometerprospektion von Viereckschanzen. In P. Neumann-Eisele (ed.), Rätselhafte, Viereckschanzen, der Kelten, Bauwerke, II-22. Kelheim, Museumsheft 8.

Fassbinder, J. W. E. 20I5. Seeing beneath the farmland, steppe and desert soil: magnetic prospecting and soil magnetism. Journal of Archaeological Science 56: 85-95.

Fassbinder, J. W. E. 20I7. Magnetometry for archaeology. In S. Gilbert and S. Allan (eds), Encyclopedia of Geoarchaeology. Springer.

Fassbinder, J. W. E., Narr, D., Linck, R., Deller, T. and Becker, F. 20II. Prospektion am römischen Kastell Großprüfening. Das archäologische Jahr in Bayern 2010: 92-95.

Herwanger, J. H., Maurer, A. G., Green, J. and Leckebusch, J. 2000. 3-D inversions of magnetic gradiometer data in archaeological prospecting: Possibilities and limitations. Geophysics 65(3): 849-860.

Issawi, B. I97I. Geology of Darb El-Arbain, Western Desert, Egypt. Annals of the Geological Survey of Egypt I: 53-92.

Klitzsch, E. 1983. Paleozoic formations and a carboniferous glaciation from the Gilf Kebir-Abu Ras area in southwestern Egypt. Journal of African Earth Sciences I: 17-19.

Maher, B. 20II. The magnetic properties of Quaternary aeolian dusts and sediments, and their Quaternary palaeoclimatic significance. Aeolian Res 3: 87-I44. 
234 Fabian Welc and Przemystaw Bobrowski

Osman, R. 1999. Geological interpretation of the main geomorphic units in Egypt. In B. Issawi, M. El Hinnawi, M. Francis and A. Mazhar (eds), The Phanerozaic Geology of Egypt, A Geodynamic Approach, 7-54. Cairo, The Egyptian Geological Survey Special Publication No. 76.

Schild, R. and Wendorf, F. 20I3. Early and middle Holocene paleoclimates in south western desert of Egypt - The world before unification. Studia Quaternaria 30(2): 125-I33.

Sherbini, M. I., Kora, El. M. and Issai, G. H. 1989. Mineralogy and geochemistry of the Late CretaceousEarly Tertiary sediments in southwestern Egypt. Journal Univrsity of Kuwait (Sci.) 16: 365-364.

Welc, F., Nebelsick, L. D. and Wach. D. 20I9. The first Neolithic roundel discovered in Poland reinterpreted with the application of the geophysical Amplitude Data Comparison (ADC) method. Archeological Prospection 26(4): 283-297.

Wendorf, F., Schild, R. and Associates. 200I. Holocene settlement of the Egyptian Sahara. Vol. I: The Archaeology of the Nabta Playa. New York, Boston, Dordrecht, London, Moscow. 